\title{
Docking Study, Synthesis, and Anti-Inflammatory Potential of Some New Pyridopyrimidine-Derived Compounds
}

\author{
Mohamed A Abdelgawad (D)', Mohammad M Al-Sanea', Arafa Musa $\mathbb{D}^{2}$, Mohammed Elmowafy ${ }^{3}$, \\ Ashraf K El-Damasy ${ }^{4}$, Amany A Azouz ${ }^{5}$, Mohammed M Ghoneim $\mathbb{D}^{6}$, Rania B Bakr ${ }^{7}$ \\ 'Department of Pharmaceutical Chemistry, College of Pharmacy, Jouf University, Sakaka, Al Jouf, 7234I, Saudi Arabia; ${ }^{2}$ Department of Pharmacognosy, \\ College of Pharmacy, Jouf University, Sakaka, 7234I, Saudi Arabia; ${ }^{3}$ Department of Pharmaceutics, College of Pharmacy, Jouf University, Sakaka, Saudi Arabia; \\ ${ }^{4}$ Department of Medicinal Chemistry, Faculty of Pharmacy, Mansoura University, Mansoura, 355I6, Egypt; ${ }^{5}$ Department of Pharmacology and Toxicology, \\ Beni-Suef University, Beni-Suef, 625 14, Egypt; ${ }^{6}$ Department of Pharmacy Practice, College of Pharmacy, AlMaarefa University, Ad Diriyah, I37I3, Saudi \\ Arabia; ${ }^{7}$ Department of Pharmaceutical Organic Chemistry, Faculty of Pharmacy, Beni-Suef University, Beni- Suef, 625I4, Egypt
}

Correspondence: Mohamed A Abdelgawad, Tel +9665954352/4, Fax +966-14 23 I7958, Email mhmdgwd@ju.edu.sa; mohamedabdelwahab976@yahoo.com

Background and Purpose: Because of gastrointestinal irritation and kidney toxicity associated with non-steroidal anti-inflammatory drugs and the cardiovascular problems of Coxibs use, developing novel anti-inflammatory agents with reduced toxicity and improved selectivity remains a major challenge. Depending on our previous work, a novel series of pyridopyrimidinones IIIa-i has been synthesized via reaction of 6-amino-2-thioxo-2,3-dihydro-1H-pyrimidin-4-one (I) and phenyldiazenyl aromatic aldehydes (IIa-i). All the new constructed compounds were fully characterized by elemental and spectral analysis.

Methods: The target compounds IIIa-i were investigated for their potential towards COX inhibition, anti-inflammatory properties using carrageenan induced edema model in rat paw, and the ulcer indices of the most active members.

Results: The ethyl pyridopyrmidinone-benzoates IIIf, IIIg and IIIh showed superior inhibitory activity of carrageenan induced edema to celecoxib. Furthermore, the pyridopyrimidinones IIId, IIIf, IIIg, and IIIi exerted improved COX-2 inhibitory activity (IC 50 $=0.67-1.02 \mu \mathrm{M})$ comparing to celecoxib $\left(\mathrm{IC}_{50}=1.11 \mu \mathrm{M}\right)$. Moreover, the gastric ulcerogenic potential assay of compounds IIIf$\mathbf{h}$ revealed their lower ulcerogenic liability than indomethacin with comparable effect to celecoxib.

Conclusion: Virtual docking investigation of the most active candidates IIId, IIIf, IIIg and IIIi in the active site of COX-2 enzyme showed that these compounds implied interaction and binding motif similar to the cocrystallized ligand bromocelecoxib.

Keywords: cyclooxygenase inhibitors, anti-inflammatory activity, ulcerogenic effects, tricyclic pyridopyrimidines

\section{Introduction}

Inflammation is a cellular reaction to any harmful stimuli and conditions like tissue damage and infection. ${ }^{1-3}$ This physiological response includes the delivery of blood components to the local infection site or injury triggering vasodilation and increased vascular permeability. ${ }^{4-7}$ NSAIDs (Non-steroidal anti-inflammatory drugs) are clinically indicated for relieving fever, pain, and inflammation by suppressing cyclooxygenase (COX) enzymes. ${ }^{8,9}$ Cyclooxygenases (COXs) are key enzymes responsible for transforming arachidonic acid, which is released on affected tissues by the effect of phospholipase A2 to various prostaglandins. ${ }^{10,11}$ The major two isoforms of cyclooxygenase are COX-1 and 2. ${ }^{12}$ The constitutive COX-1 mediates the formation of diverse cytoprotective prostaglandins, which are responsible for lining the gastric mucosa, inducing platelet aggregation and preserving homeostasis. ${ }^{13,14}$ However, the inducible COX-2 is accountable for synthesizing of pain and inflammatory mediating prostaglandins. ${ }^{15,16}$

Conventional NSAIDs non-selectively inhibit COX-1 and 2 isozymes, therefore their administration is associated with gastrointestinal side effects. ${ }^{17-19}$ Therefore, selective COX-2 inhibitors were developed to achieve enhanced safety profile on gastric mucosa. Nonetheless, certain members such as rofecoxib and valdecoxib have been associated with 
increased probability of myocardial infarction incidences as well as hypertensive actions. ${ }^{20}$ In this regard, discovery of selective COX-2 blockers for management of pain and inflammation with diminished side actions emerged as an urgent medical need.

The pyridine nucleus has been incorporated in many core structures of several anti-inflammatory agents. ${ }^{21-23}$ For example, the trifluoromethanesulfonamide pyridine (1) (Figure 1) was reported as COX-2 inhibitor with higher COX-2 selectivity index $(\mathrm{SI}=15.35)$ than celecoxib $(\mathrm{SI}=7.46) .{ }^{24}$ Moreover, Chung et al reported a set of different tricyclic chromeno-pyridines as promising anti-inflammatory agents. ${ }^{25}$ As a representative example, compound 2 exerted potent anti-inflammatory effect through reducing the formation of $\mathrm{PGE}_{2}$ at $10-20 \mathrm{mg} / \mathrm{kg}$ dose. Furthermore, the pyridoacylsulfonamide derivative 3 was described as COX-2 inhibitor with $\mathrm{IC}_{50}$ equal to $5.6 \mu \mathrm{M},{ }^{26}$ and it strongly inhibited $\mathrm{PGE}_{2}$ $\left(\mathrm{IC}_{50}=0.15 \mu \mathrm{M}\right)$ in a comparable potency to celecoxib $\left(\mathrm{IC}_{50}=0.10 \mu \mathrm{M}\right)$.

On the contrary, a number of pyrimidine-based small molecules have been reported as potent anti-inflammatory candidates. $^{27}$ As an example, the hexahydroimidazo[1,2-c]pyrimidine 4 was documented to possess $34.3 \%$ antiinflammatory activity at $50 \mathrm{mg} / \mathrm{kg}$ dose. ${ }^{28}$ Furthermore, Keche et al reported a series of pyrimidine-diarylurea conjugates such as compound $\mathbf{5}$, which demonstrated higher inhibitory properties against interleukin IL-6 (96\%) and proactive

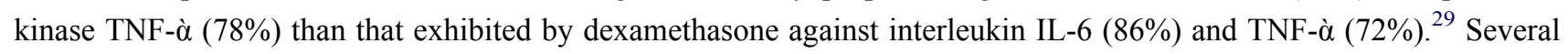

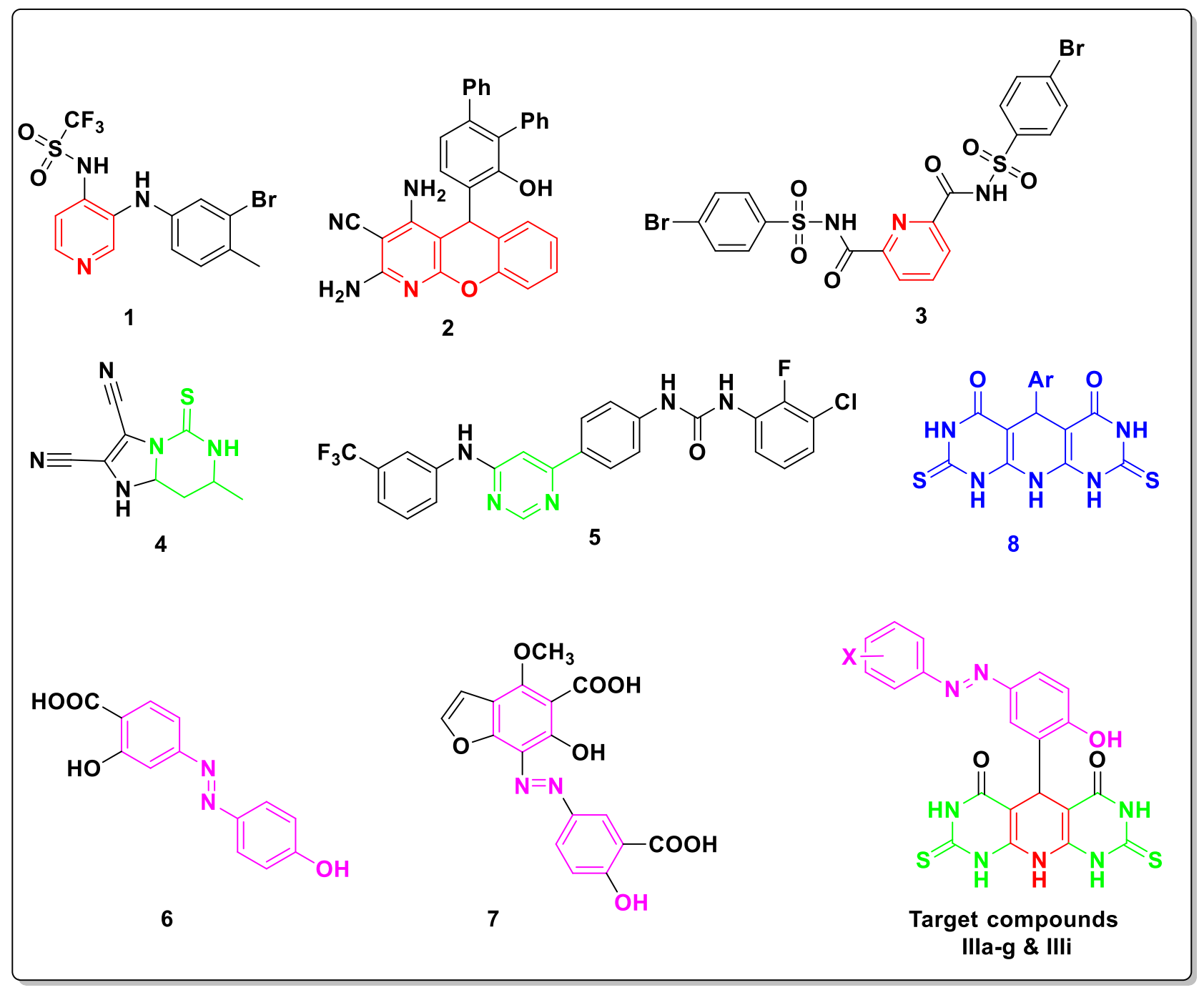

Figure I Representative examples of previously identified anti-inflammatory pyridines (I-3), pyrimidines $(\mathbf{4}, \mathbf{5})$, azo containing derivatives $(\mathbf{6}, \mathbf{7})$, tricyclic pyridopyrimidine (8), and target compounds IIla-i. 

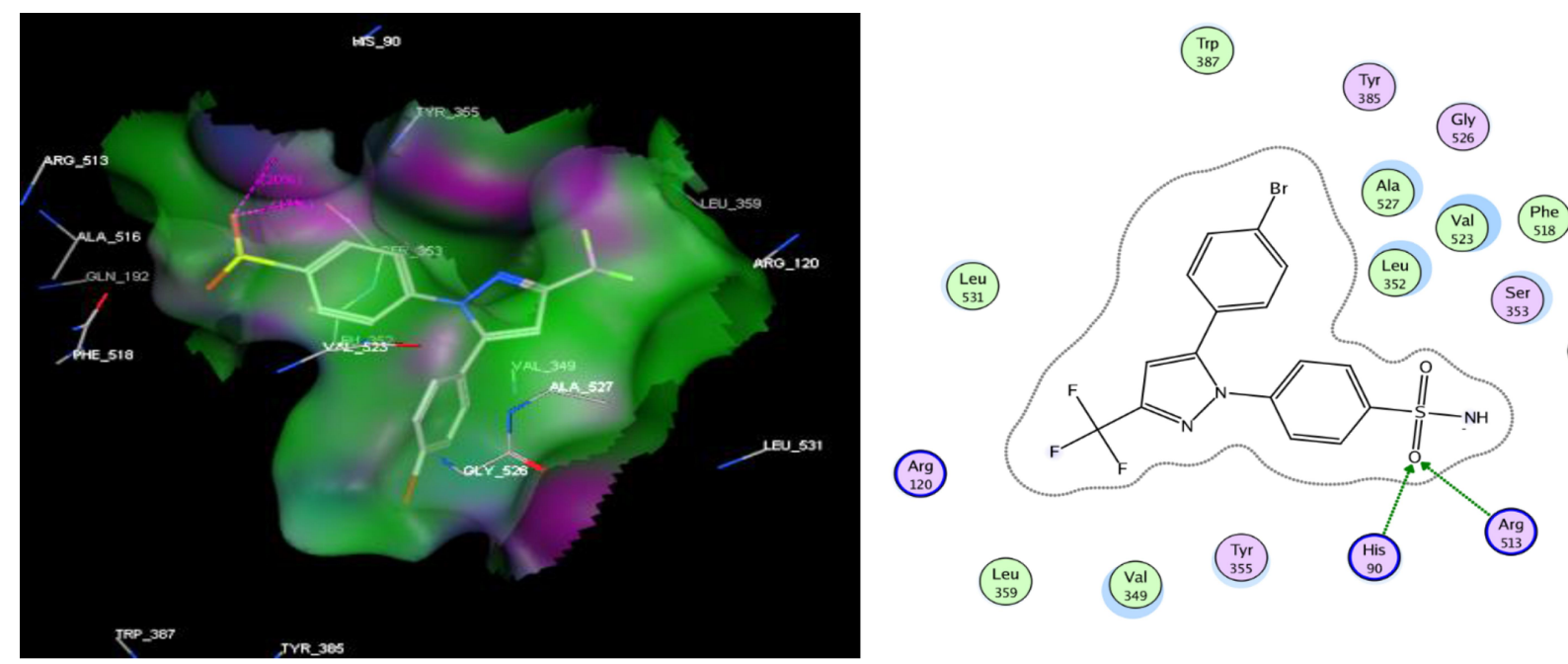

Figure 2 The 2D (right panel) and 3D (left panel) putative binding mode of SC-558.

4-(phenyldiazenyl)phenol containing compounds $\mathbf{6}$ and $\mathbf{7}$ exhibited anti-inflammatory activity in case of inflammatory bowel disease and ulcerative colitis. ${ }^{30-33}$ A variety of tricyclic pyridodipyrimidinones 8 was identified and elicited promising anti-inflammatory activities with low incidence of gastric ulcer. ${ }^{34,35}$

According to reported mentioned studies and in continuation to our former studies for identification of selective COX-2 blockers, ${ }^{12,19,36-44}$ further derivatives of pyridodipyrimidinone scaffold IIIa-i have been prepared and biologically investigated for their potential anti-inflammatory properties. The target molecules have been designed via conjugation of the privileged tricyclic pyridodipyrimidinone with 4-(phenyldiazenyl) phenol structural feature in a single chemical entity in an attempt to achieve selective COX-2 blocking activity along with favorable anti-inflammatory activity and minimized gastric side effects (Figure 1).

\section{Results and Discussion}

\section{Chemistry}

The key building block, pyrimidine-4-one (I) and phenyldiazenyl aromatic aldehydes IIa-i, were chemically synthesized as shown in Scheme 1. Condensation of the ethyl cyanoacetate ester with thiourea in presence of sodium ethoxide as a strong base afforded compound $\mathbf{I}$ in quantitative yield. ${ }^{45}$ On the other hand, phenyldiazenyl aldehydes IIa-i were achieved through diazotization of various anilines followed by treatment with aromatic aldehydes under basic conditions. ${ }^{46-48}$ The synthesis of the target pyridopyrimidinones IIIa-i was accomplished in $66-93 \%$ yield by treatment of compound I with various phenyldiazenyl aromatic aldehydes in $\mathrm{CH}_{3} \mathrm{OH}$ containing a catalytic amount of $\mathrm{HCl}$ adopting the reported method. ${ }^{34}$ In this reaction, the acidic polar solvent favors the reaction progress by the creation of a 6-imino that directs to higher nucleophilic character of carbon five, causing reaction to occur on the aromatic aldehydic carbonyl (Scheme 2). The chemical structures of newly prepared compounds IIIa-i have been elucidated via different spectroscopic and elemental analysis. ${ }^{1} \mathrm{HNMR}$ data for the novel compounds IIIa-i is shown in Table 1.

\section{Pharmacological Activity Assay of COX Inhibition}

The newly prepared azo molecules IIIa-i were investigated for their COX blocking action - in terms of $\mathrm{IC}_{50}-$ by enzyme immunoassay (EIA) utilizing ovine COX-1/2 assay kit. Furthermore, SI (selectivity index) was assessed as $\mathrm{IC}_{50}$ against $\mathrm{COX}-1 / \mathrm{IC}_{50}$ against $\mathrm{COX}-2$ applying positive standard celecoxib. As shown in Table 2, the obtained data pointed out that the pyridopyrimidinones IIIa-i exhibited modest to moderate blocking activity to COX-1 $\left(\mathrm{IC}_{50}=3.25-11.23\right.$ $\mu \mathrm{M})$, and favorable suppressing activity for $\mathrm{COX}-2\left(\mathrm{IC}_{50}=0.67-4.78 \mu \mathrm{M}\right)$. While the pyridopyrimidinone IIId, 
<smiles>[CH2+]COC(=O)CC#N</smiles>

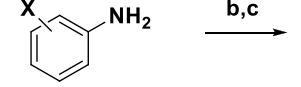

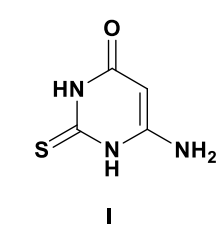

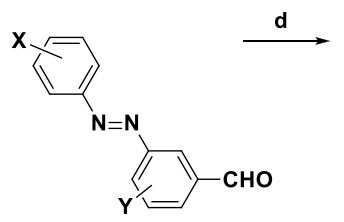

Ila-i
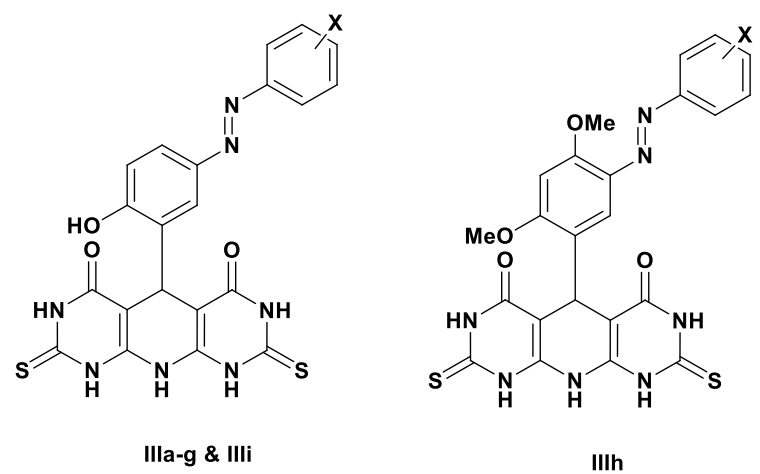

$\mathrm{Y}=4-\mathrm{OH}, 2,4-\mathrm{OMe}$

\begin{tabular}{r|ll|ll|l} 
& $\mathbf{X}$ & & $\mathbf{X}$ & & $\mathbf{X}$ \\
\hline IIIa & $3-\mathrm{Me}$ & IIId & $3,4-\mathrm{OMe}$ & IIIg & $4-\mathrm{Br}$ \\
IIIb & $4-\mathrm{OMe}$ & IIle & $3,5-\mathrm{Cl}$ & IIIh & 4-COOEt \\
IIIc & $3-\mathrm{Cl}-4-\mathrm{F}$ & IIIf & $4-\mathrm{COOEt}$ & IIII & 4-(Benzothiazol-2-yl)
\end{tabular}

Scheme I The synthetic pathway of molecules Illa-i. Reagents and conditions: a) $\mathrm{NaOC} 2 \mathrm{H} 5, \mathrm{C} 2 \mathrm{H} 5 \mathrm{OH}$, reflux, $6 \mathrm{~h}, 99 \%$; b) $\mathrm{NaNO} 2, \mathrm{HCl}, 0$ oC, $2 \mathrm{~h}$; c) Aromatic aldehyde, $\mathrm{NaOH}$, stirring, 0 oC, 12 h; d) conc. $\mathrm{HCl}$, methanol, rt, 7h, 66-93\%.
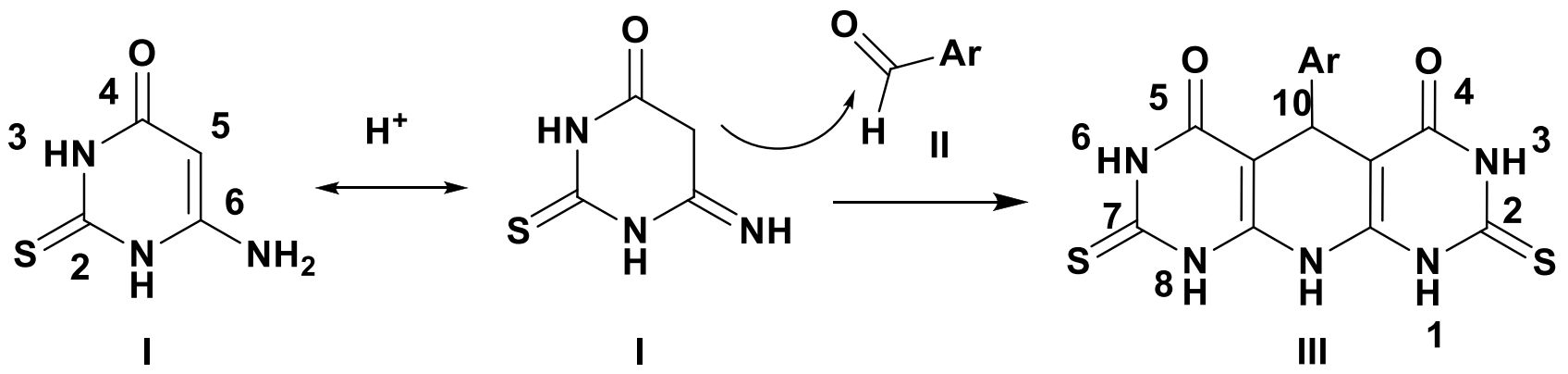

Scheme 2 The reasonable mechanism for compound III formation.

possessing 3,4-dimethoxyphenyl, was the highest $\mathrm{COX}-2$ blocker $\left(\mathrm{IC}_{50}=0.67 \mu \mathrm{M}\right)$, IIIf emerged as the best selective member to COX-2 $(\mathrm{SI}=11.82)$ being superior to celecoxib.

The nature of substitution pattern on both proximal and distal phenyl rings of pyridopyrimidinone had a substantial role in modulating compound's selectivity and activity against COX-2. The hydroxybenzaldehyde derived pyridopyrimidinones IIId (COX-2, IC I0 $\left._{2}=0.67 \mu \mathrm{M}\right)$, IIII $\left(\mathrm{COX}-2, \mathrm{IC}_{50}=0.69 \mu \mathrm{M}\right)$, IIIf $\left(\mathrm{COX}-2, \mathrm{IC}_{50}=0.95 \mu \mathrm{M}\right)$, and IIIg $\left(\mathrm{COX}-2, \mathrm{IC}_{50}=1.02 \mu \mathrm{M}\right)$, elicited distinct inhibition for COX-2 in comparable pattern to celecoxib $\left(\mathrm{IC}_{50}=1.11 \mu \mathrm{M}\right)$. Upon comparing the activity of 4-ethyl carboxylate derivatives IIIf and IIIh, it was evident that appendage of hydroxyl group (IIIf; COX-2, $\mathrm{IC}_{50}=0.95 \mu \mathrm{M}, \mathrm{SI}=11.82$ ) on the proximal phenyl is advantageous than 2,4-dimethoxy substitution (IIIh; COX-2, $\mathrm{IC}_{50}=2.43 \mu \mathrm{M}, \mathrm{SI}=3.23$ ) for achieving better COX-2 suppressive activity and selectivity. Moreover, it was found that replacing the 3-chloro-4-fluorophenyl of IIIc $\left(\mathrm{COX}-2, \mathrm{IC}_{50}=3.87 \mu \mathrm{M}\right)$ with 3,4-dimethoxyphenyl led to 5.8-fold improvement in activity (IIId; COX-2, $\mathrm{IC}_{50}=0.67 \mu \mathrm{M}$ ). Of special significance, pyridopyrimidinones IIIf $(\mathrm{SI}=11.82)$ and IIIg $(\mathrm{SI}=9.02)$ displayed remarkable selectivity for COX-2 outperforming that observed for celecoxib $(\mathrm{SI}=6.61)$.

\section{In vivo Anti-Inflammatory Action}

Animal and ethics: we used in this study adult male Wister albino rats weighing 150-180g. Before any experimental study, rats are given 14 days to acclimate. The rats were kept in a controlled environment with access to water and food. All assays and practical animal studies had been done in Nahda university and adapting rules for care of animals in lab in 
Table I NMR Data of the Novel Compounds IIla-I

\begin{tabular}{|c|c|c|}
\hline $\begin{array}{l}\text { Compound } \\
\text { No. }\end{array}$ & 'HNMR & ${ }^{13}$ CNMR \\
\hline Illa & 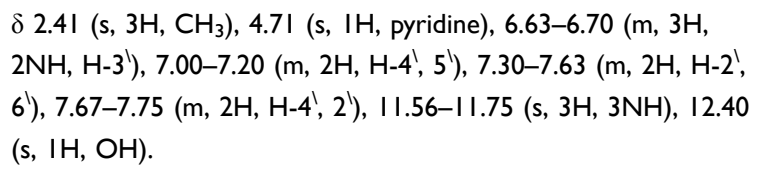 & $\begin{array}{l}\delta 21.4,29.7,78.6,115.6,120.2,120.9,122.0,124.2,125.2, \\
129.6,131.4,139.2,145.4,152.7,153.3,160.7,163.1,175.0 .\end{array}$ \\
\hline Illb & 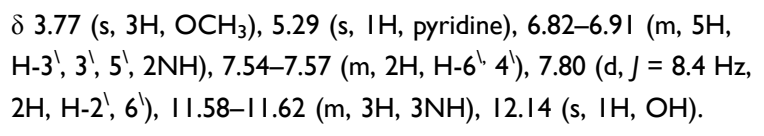 & $\begin{array}{l}\delta 29.4,56.5,90.5,113.9,115.8,121.9,123.9,125.9,125.8 \\
144.7,145.5,153.9,161.8,164.3,166.9,174.5\end{array}$ \\
\hline IIIc & 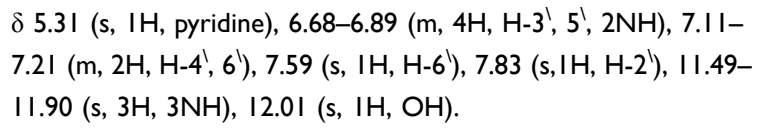 & $\begin{array}{l}\delta 29.7,91.0,115.8,117.9,121.2,121.2,122.3,123.4,125.4 \text {, } \\
126.9,145.1,149.3,153.36,160.0,162.8,168.0,173.0 .\end{array}$ \\
\hline IIII & $\begin{array}{l}\delta 3.84\left(\mathrm{~s}, 3 \mathrm{H}, \mathrm{OCH}_{3}\right), 3.86\left(\mathrm{~s}, 3 \mathrm{H}, \mathrm{OCH}_{3}\right), 5.29(\mathrm{~s}, \mathrm{IH}, \text { pyridine), } \\
6.82-6.85\left(\mathrm{~m}, 4 \mathrm{H}, \mathrm{H}-3^{\prime}, 5^{\prime}, 2 \mathrm{NH}\right), 7.1 \mathrm{I}-7.16\left(\mathrm{~m}, 2 \mathrm{H}, \mathrm{H}-2^{\prime}, 6^{\prime}\right) \\
7.54-7.57\left(\mathrm{~m}, 2 \mathrm{H}, \mathrm{H}-6^{\prime}, \mathrm{H}-4 \mathrm{l}\right), \mathrm{II} .92-\mathrm{II} .97(\mathrm{~m}, 3 \mathrm{H}, 3 \mathrm{NH}), 12.03 \\
(\mathrm{~s}, \mathrm{IH}, \mathrm{OH}) .\end{array}$ & 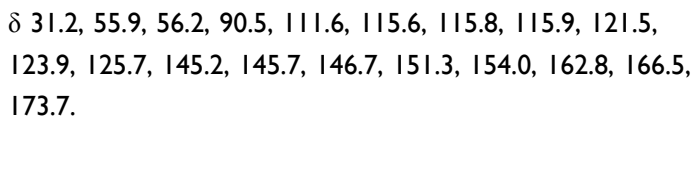 \\
\hline Ille & 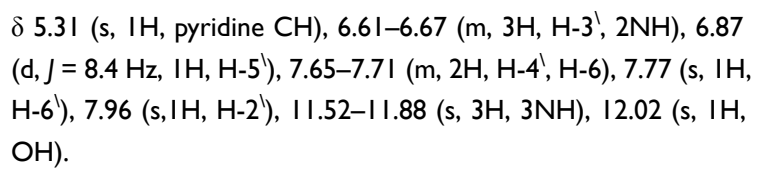 & $\begin{array}{l}\delta 29.7,89.0,115.8,121.1,121.8,122.4,125.5,129.3,135.3, \\
\mid 45.1,153.3,154.3,160.6,163.1,173.0\end{array}$ \\
\hline IIIf & 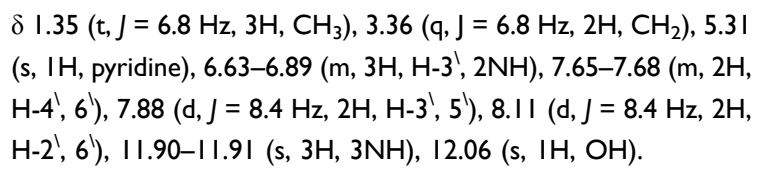 & $\begin{array}{l}\delta, 14.6,29.7,61.4,90.7,115.8,121.6,122.6,123.2,125.7 \\
130.8,131.0,145.5,153.3,155.3,160.5,163.1,165.7,172.9 .\end{array}$ \\
\hline IIIg & 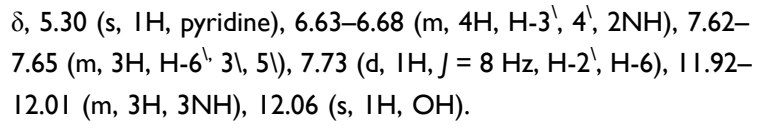 & $\begin{array}{l}\delta 29.7,78.6,115.7,121.2,123.8,124.4,125.6,126.8,132.8 \\
145.2,151.5,153.3,159.8,163.1,175.0 .\end{array}$ \\
\hline Illh & 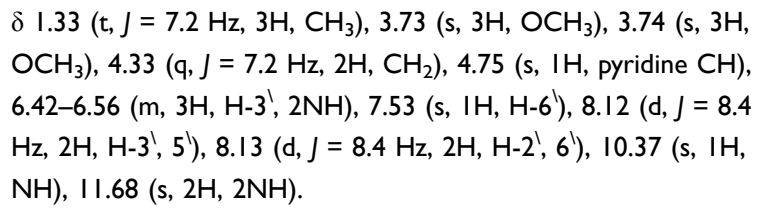 & $\begin{array}{l}\delta, 14.6,19.0,56.4,56.5,61.3,85.7,101.2,115.6,122.4,125.2, \\
130.6,130.9,153.2,156.6,165.1,167.3,168.7,174.9 .\end{array}$ \\
\hline Illi & 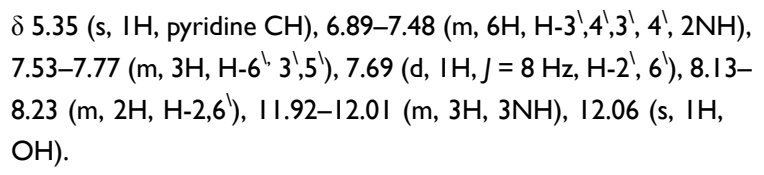 & $\begin{array}{l}\delta 29.7,90.8,115.8,121.3,122.8,123.4,123.8,125.8,126.21 \text {, } \\
127.2,134.3,135.1,145.5,153.3,154.0,154.0,160.1,166.6 \text {, } \\
166.8,173.0 .\end{array}$ \\
\hline
\end{tabular}

accordance with NIH Guidelines for the Care and Use of Laboratory Animals. The design of the current work was authorized from Nahda University ethical committee, Beni-Suef, Egypt (NUB-059-019).

Carrageenan induced edema model in rat paw was used to evaluate the anti-inflammatory activity of the target candidates IIIa-i and celecoxib was chosen as the positive control.

The pyridopyrimidinones were orally administrated in a dose of $50 \mathrm{mg} / \mathrm{kg}$ nearly earlier persuading inflammation through SC (subcutaneous injection) of carrageenan. Inhibition of carrageenan induced inflammation was estimated by measuring the changes of paw dimensions after 1,3 and $5 \mathrm{~h}$ (Table 3). The obtained findings showed that the pyridopyrimidinones IIIf and IIIh had superior anti-inflammatory properties than celecoxib at the three examined 
Table 2 In vitro COXs Inhibitory Action of Molecules IIla-i

\begin{tabular}{|l|c|c|c|}
\hline \multirow{2}{*}{ Compound No. } & \multicolumn{2}{|c|}{ IC $_{\mathbf{5 0}}(\mu \mathrm{M})^{\mathrm{a}}$} & \multirow{2}{*}{ SI $^{\mathrm{b}}$} \\
\cline { 2 - 3 } & COX-I & COX-2 & \\
\hline IIIa & $7.88 \pm 0.14$ & $4.78 \pm 0.08$ & 1.65 \\
IIIb & $6.86 \pm 0.12$ & $2.51 \pm 0.09$ & 2.73 \\
IIIc & $10.52 \pm 0.24$ & $3.87 \pm 0.07$ & 2.72 \\
IIId & $4.00 \pm 0.09$ & $\mathbf{0 . 6 7} \pm 0.02$ & 5.97 \\
IIle & $7.52 \pm 0.11$ & $2.11 \pm 0.07$ & 3.56 \\
IIIf & $I I .23 \pm 0.27$ & $\mathbf{0 . 9 5} \pm 0.01$ & 11.82 \\
IIIg & $9.20 \pm 0.22$ & $1.02 \pm 0.03$ & 9.02 \\
IIIh & $7.84 \pm 0.16$ & $2.43 \pm 0.07$ & 3.23 \\
IIIi & $3.25 \pm 0.07$ & $\mathbf{0 . 6 9} \pm 0.02$ & 4.71 \\
Celecoxib & $7.34 \pm 0.18$ & $1.11 \pm 0.04$ & 6.61 \\
\hline
\end{tabular}

Notes: ${ }^{\mathrm{a}} \mathrm{C}_{50}$ : compound concentration required to produce $50 \%$ inhibition of $\mathrm{COX}-\mathrm{I}$ or $\mathrm{COX}-2$ for means of three determinations, bold figures refer to submicromolar; ${ }^{b} \mathrm{SI}=I_{50}(\mathrm{COX}-\mathrm{I}) / \mathrm{IC}_{50}(\mathrm{COX}-2)$.

Table 3 In vivo Anti-Inflammatory Activities of Compounds IIIa-i

\begin{tabular}{|c|c|c|c|}
\hline \multirow[t]{2}{*}{ Compound No. } & \multicolumn{3}{|c|}{ Anti-Inflammatory Activity \% (AI) ${ }^{a}$} \\
\hline & I h & $3 \mathbf{h}$ & $5 \mathbf{h}$ \\
\hline IIla & $0.95 \pm 0.10 *(34 \%)$ & $0.83 \pm 0.12 *(41 \%)$ & $0.85 \pm 0.06 *(39 \%)$ \\
\hline IIIb & $1.00 \pm 0.11 *(31 \%)$ & $0.95 \pm 0.12(32 \%)$ & $0.90 \pm 0.14(36 \%)$ \\
\hline IIIc & $1.10 \pm 0.08(24 \%)$ & $1.00 \pm 0.10(29 \%)$ & $0.65 \pm 0.05^{* * *}(54 \%)$ \\
\hline IIId & $1.05 \pm 0.10(28 \%)$ & $0.95 \pm 0.12(32 \%)$ & $1.05 \pm 0.13(55 \%)$ \\
\hline IIle & $1.05 \pm 0.12(28 \%)$ & $0.95 \pm 0.09(32 \%)$ & $0.78 \pm 0.08 * *(45 \%)$ \\
\hline IIIf & $0.60 \pm 0.12 * * *(52 \%)$ & $0.58 \pm 0.11 * * *(59 \%)$ & $0.48 \pm 0.14^{* * *}(66 \%)$ \\
\hline IIIg & $1.08 \pm 0.09(26 \%)$ & $0.65 \pm 0.13 * * *(54 \%)$ & $0.60 \pm 0.15^{* * *}(57 \%)$ \\
\hline IIIh & $0.49 \pm 0.05 * * *(67 \%)$ & $0.58 \pm 0.11 * * *(63 \%)$ & $0.58 \pm 0.17 * * *(57 \%)$ \\
\hline IIli & $1.10 \pm 0.14(24 \%)$ & $0.80 \pm 0.15^{* *}(43 \%)$ & $0.68 \pm 0.13^{* *}(52 \%)$ \\
\hline Control & $1.45 \pm 0.15(0 \%)$ & $1.58 \pm 0.15(0 \%)$ & $1.33 \pm 0.10(0 \%)$ \\
\hline Celecoxib & $0.83 \pm 0.09 * *(43 \%)$ & $0.80 \pm 0.11 * *(43 \%)$ & $0.65 \pm 0.10^{* * *}(54 \%)$ \\
\hline
\end{tabular}

Notes: ${ }^{a}$ The presented values are the average of triplicate experiments \pm SEM, Significance levels $*_{p}<0.05, * * p<0.01$ and $* * * p<0.00 I$ as compared to the control group.

time intervals. In addition, the target compound IIIg exhibited higher anti-inflammatory potential than displayed by celecoxib after 3 and 5 hours.

Close inspection of the results listed in Table 3 underscored that the pyridopyrimidinone derivatives substituted with ethyl ester IIIf (Anti-inflammatory (AI) \% = 52-66) and IIIh (AI \% = 57-67) displayed higher activity for inhibition of edema than those congeners containing either electron donating (IIId; AI \%=28-55) or electron withdrawing (IIIc; AI $\%=24-54$ ) groups, particularly after 1 and 3 hours. In harmony with the COX-2 inhibitory assessment, the 4-benzothiazol-2-yl containing pyridopyrimidinone IIIi exerted superior in vivo anti-inflammatory activity than its corresponding methoxy derivative IIIb. Moreover, introducing bromine on compound IIIg augmented the anti-inflammatory activity (3 $\mathrm{h} ; \mathrm{AI} \%=54,5 \mathrm{~h} ; \mathrm{AI} \%=57$ ).

The ethyl acetoxy group in compounds IIIf and IIIh has important role in vivo activity anti-inflammatory activity also bromine at for position 4 in compound IIIg. Also, the ethyl acetoxy group in IIIf and IIIh increases absorption so fast onset of action consequently high anti-inflammatory activities $52 \%$ and $67 \%$ respectively but bromine in IIIg delay onset of action firstly in compared with IIIf and IIIh. 
Table 4 Gastric Ulcerogenic Effect of Compounds IIIf-h

\begin{tabular}{|l|c|c|c|}
\hline Comp. No. & Ulcer Number & Ulcer Index & Relative Ulcerogenicity to Celecoxib \\
\hline IIIf & $3.75 \pm 0.15$ & $3.75 \pm 0.11$ & 1.25 \\
IIIg & $6.75 \pm 0.07$ & $4.75 \pm 0.14$ & 1.58 \\
IIIh & $6.50 \pm 0.11$ & $5.25 \pm 0.13$ & 1.75 \\
Celecoxib & $3.25 \pm 0.17$ & $3.00 \pm 0.09$ & 1 \\
Indomethacin & $14.25 \pm 0.31$ & $22.5 \pm 0.21$ & 7.5 \\
\hline
\end{tabular}

\section{Ulcerogenic Liability}

The top three active pyridopyrimidinones IIIf-h were further evaluated for their gastric ulcerogenic liability in rats (Table 4). The ulcerogenicity liability of the investigated pyridopyrimidinones was compared with both COX-1 inhibitor (indomethacin) and COX-2 inhibitor (celecoxib). Interestingly, compound IIIf had the lowest ulcerogenic effect, which might be attributed to its potential selectivity for COX-2 (SI = 11.82). Additionally, all of the tested candidates showed lower ulcerogenic action than the standard indomethacin.

\section{Molecular Docking Studies}

To acquire insights about the underlying mechanism of action of the newly investigated pyridopyrimidinones, virtual docking of the highly selective COX-2 inhibitors IIId, IIIf, IIIg and IIIi within the active binding site of COX-2 enzyme was studied. The co-crystal structure of COX-2 complex with SC-558, a selective COX-2 blocker, was acquired from PDB (protein data bank: 1CX2), ${ }^{49}$ and the virtual docking was conducted using MOE (Molecular Operating Environment; 2010). Validation of docking protocol had been performed by redocking the ligand bromocelecoxib (SC-558) into COX-2 active site with root mean standard deviation (RMSD) of 1.1524, and showed an energy score (S) of $-11.93 \mathrm{kcal} / \mathrm{mol}$. The ligand sulphonyl group was engaged in two hydrogen bonds with the receptor amino acids His90 and Arg513 (Figure 2, Table 5).

Interestingly, compound IIIf showed profitable fitting with COX-2 with superior docking score ( $\mathrm{S}=-13.89 \mathrm{kcal} / \mathrm{mol}$ ) to bromocelecoxib ( $\mathrm{S}=-11.93 \mathrm{kcal} / \mathrm{mol})$. Furthermore, IIIf displayed two HB interactions through its carbonyl oxygen with $\operatorname{Arg} 120$ (2.65 $\mathrm{A}^{\circ}$ ) as well as azo moiety with His90 (3.25 A ${ }^{\circ}$ (Figure 3; Table 5). Also, the pyridopyrimidinone IIIg exhibited score energy (S) of $-11.20 \mathrm{kcal} / \mathrm{mol}$, and was able to form three HB interactions with $\operatorname{Arg} 120$, His90 and Tyr355 (Figure 3).

\section{Conclusion}

Novel derivatives of pyridopyrimidinones IIIa-i were prepared and assessed in vitro and in vivo for their COXs and carrageenan induced edema anti-inflammatory activities, respectively. Preliminary screening of the target compounds disclosed that the pyridopyrimidinone IIIf possessing ethyl acetate had the best activity with potent edema inhibition in percent $=52 \%$ after one hour, $59 \%$ after three hours and $66 \%$ after five hours. Moreover, certain members among this focused library were identified to be selective COX-2 inhibitors. Particularly, IIId, IIIf, IIIg and IIIi, exerted superior inhibition for COX-2 $\left(\mathrm{IC}_{50}=0.67-1.02 \mu \mathrm{M}\right)$ than celecoxib $\left(\mathrm{IC}_{50}=1.11 \mu \mathrm{M}\right)$. Ulcerogenic accountability of compounds IIIf-h exhibited their comparable activity to celecoxib along with less ulcerogenic effect than indomethacin. It was noted that the lipophilic group (ethyl ester or benzothiazol-2-yl) containing compounds IIIf, IIIh and IIIi elicited superior antiinflammatory effect and better selectivity for COX-2 than other derivatives. Overall, combining the privileged pyridodipyrimidinone scaffold with diphenylazo structural feature in single molecule with appropriate hydrophobic substitution pattern may represent a promising core structure for further design of potent anti-inflammatory agents with minimized gastric side effects. 

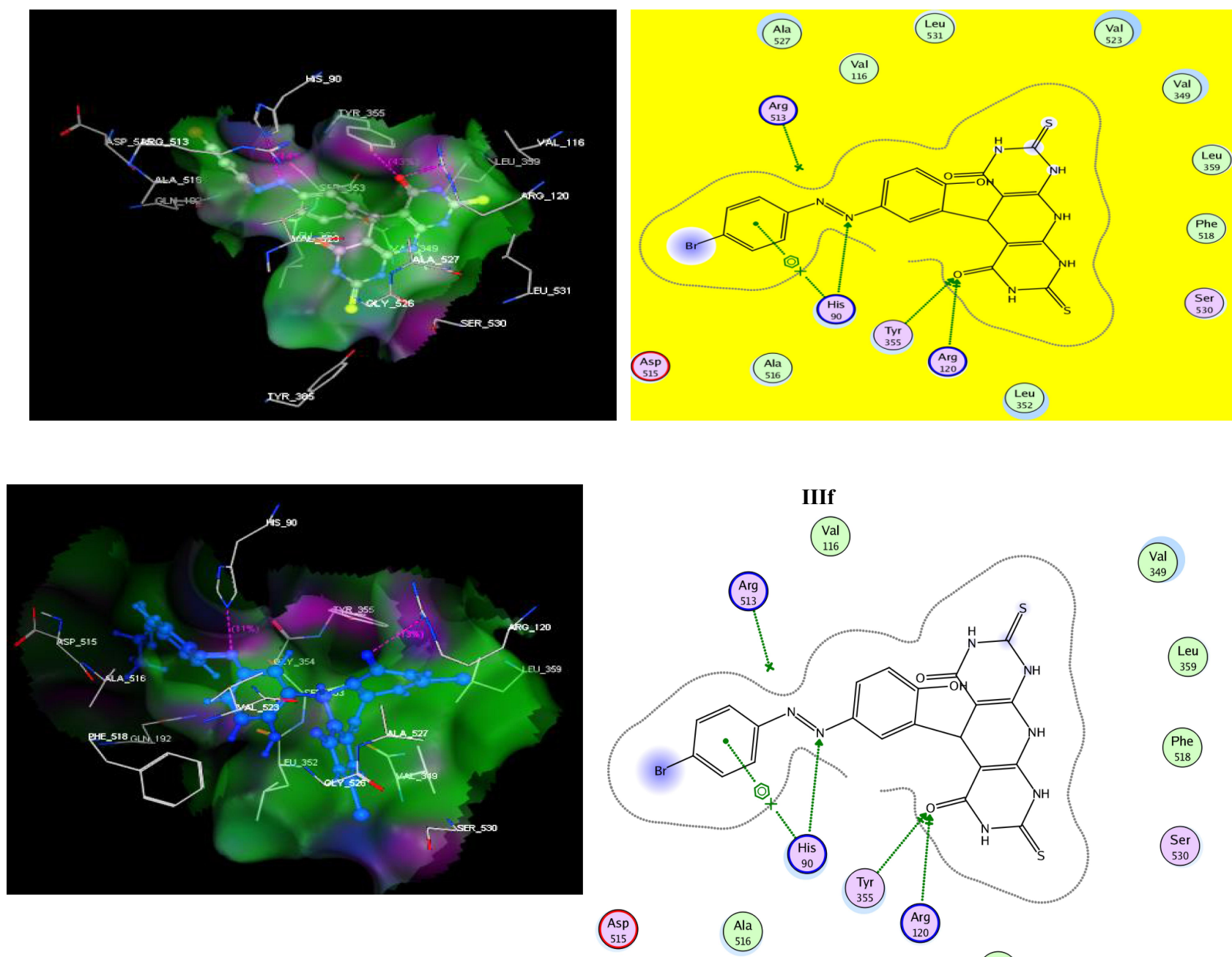

IIIg

Figure 3 The 2D (right panel) and 3D (left panel) putative binding mode of compounds IIIf and IIIg.

\section{Experimental}

\section{Chemistry}

Melting points were determined with Thomas-Hoover capillary apparatus and uncorrected. Infrared (IR) spectra of the new compounds were detected utilizing FT-IR spectrometer (Nicolet 550 Series II Magna) as films on NaCl plates, and expressed in wave number $\left(\mathrm{cm}^{-1}\right)$. ${ }^{1} \mathrm{H}$ NMR and ${ }^{13} \mathrm{C}$ NMR spectra were recorded with Bruker Avance III $400 \mathrm{MHz}$ in deuterated dimethyl sulfoxide (DMSO- $d_{6}$ ). Chemical shifts were measured in ppm ( $\delta$ scale), and the coupling constant $(J)$ values were expressed in Hertz $(\mathrm{Hz})$. Mass spectra were recorded using Hewlett Packard 5988 spectrometer. Elemental microanalyses for $\mathrm{N}, \mathrm{C}$, and $\mathrm{H}$ were measured utilizing Perkin-Elmer 2400 analyzer (Perkin-Elmer, Norwalk, CT, USA), at Cairo University (Micro analytical unit), Egypt, and all analyzed compounds were within \pm $0.4 \%$ of the assessed values. Thin layer chromatography (TLC) was carried out utilizing silica gel plates (Germany, MERCK 60F 254, $0.25 \mathrm{~mm})$, a mixture of chloroform /methanol (9.5:0.5 mL) as eluent and visualized with UV lamp. All chemicals and reagents were commercially purchased and used directly without purification. 6-Aminopyrimidinone derivative $\mathbf{I}$ and the aldehyde derivatives IIa-i were prepared adopting the reported methods. ${ }^{45,50,51}$ 
Table 5 The Virtual Docking Data of Compounds IIId, IIIf, IIIg, IIli and SC-558

\begin{tabular}{|c|c|c|c|c|c|}
\hline Compound No. & Affinity Kcal/ & No. of HBs & Distance & in Residue & Functional Group \\
\hline IIId & -13.95 & 5 & $\begin{array}{l}2.97 \\
3.20 \\
2.99 \\
3.28 \\
2.97\end{array}$ & $\begin{array}{c}\text { Tyr355 } \\
\text { His90 } \\
\text { Ser353 } \\
\text { Ser530 } \\
\text { Tyr385 }\end{array}$ & $\begin{array}{c}\mathrm{C}=\mathrm{O} \\
\mathrm{OH} \\
\mathrm{OH} \\
\mathrm{OCH}_{3} \\
\mathrm{OCH}_{3}\end{array}$ \\
\hline Illf & -13.89 & 2 & $\begin{array}{l}2.65 \\
3.25\end{array}$ & $\begin{array}{c}\text { Arg } 120 \\
\text { His } 90\end{array}$ & $\begin{array}{l}C=O \\
N=N\end{array}$ \\
\hline IIIg & -11.20 & 3 & $\begin{array}{l}2.68 \\
2.15 \\
2.98\end{array}$ & $\begin{array}{c}\text { Arg } 120 \\
\text { His } 90 \\
\text { Tyr355 }\end{array}$ & $\begin{array}{l}C=O \\
N=N \\
C=O\end{array}$ \\
\hline Illi & -14.52 & 3 & $\begin{array}{l}3.11 \\
2.87 \\
3.09\end{array}$ & $\begin{array}{c}\text { Argl20 } \\
\text { His90 } \\
\text { Tyr355 }\end{array}$ & $\begin{array}{l}C=O \\
N=N \\
C=O\end{array}$ \\
\hline SC-558 & -11.93 & 2 & $\begin{array}{l}2.41 \\
2.30\end{array}$ & $\begin{array}{c}\text { Arg513 } \\
\text { His } 90\end{array}$ & $\begin{array}{l}-\mathrm{SO}_{2} \\
-\mathrm{SO}_{2}\end{array}$ \\
\hline
\end{tabular}

Synthesis of Pyridopyrimidinones IIla-i

6-Amino-2-thioxo-2,3-dihydro-1 $\mathrm{H}$-pyrimidin-4-one (I) $(2.86 \mathrm{~g}, 20 \mathrm{mmol})$, appropriate aromatic aldehyde (IIa-i) (10 $\mathrm{mmol})$, and conc. hydrochloric acid $(5 \mathrm{~mL})$ in methanol $(30 \mathrm{~mL})$ were stirred at room temperature (rt) for $7 \mathrm{~h}$. The precipitated product was collected, washed with cold ethyl alcohol, dried and crystallized from DMF to afford the target molecules IIIa-i in pure forms.

5-(2-Hydroxy- 5-(m-Tolyldiazenyl) Phenyl)-2,8- Dithioxo-2, 3, 5, 8, 9, 10-Hexahydropyrido[2,3-D:6,5d']Dipyrimidine4,6-(IH,7H)-Dione (IIla)

Yield (85\%), yellowish white crystals, m.p. > $300{ }^{\circ} \mathrm{C}$; IR $\left(\mathrm{cm}^{-1}\right)$ : $1649(\mathrm{C}=\mathrm{O}), 3223(\mathrm{NH}), 3415(\mathrm{OH}) ;{ }^{1} \mathrm{H}$ NMR $\delta 2.41(\mathrm{~s}$, $\left.3 \mathrm{H}, \mathrm{CH}_{3}\right), 4.71$ (s, $1 \mathrm{H}$, pyridine), 6.63-6.70 (m, 3H, 2NH, H-3 $), 7.00-7.20\left(\mathrm{~m}, 2 \mathrm{H}, \mathrm{H}-4^{`}, 5^{\prime}\right), 7.30-7.63$ (m, 2H, H-2, $\left.6^{\prime}\right)$, 7.67-7.75 (m, 2H, H-4', $\left.2^{\prime}\right), 11.56-11.75$ (s, 3H, 3NH), 12.40 (s, 1H, OH); ${ }^{13} \mathrm{C}$ NMR $\delta 21.4,29.7,78.6,115.6,120.2$, 120.9, 122.0, 124.2, 125.2, 129.6, 131.4, 139.2, 145.4, 152.7, 153.3, 160.7, 163.1, 175.0; EIMS (m/z) $491\left(\mathrm{M}^{+}, 19.44 \%\right)$. Elemental analysis of $\mathrm{C}_{22} \mathrm{H}_{17} \mathrm{~N}_{7} \mathrm{O}_{3} \mathrm{~S}_{2}: \mathrm{C}, 53.76 ; \mathrm{H}, 3.49 ; \mathrm{N}, 19.95$. Found: $\mathrm{C}, 53.40 ; \mathrm{H}, 3.56 ; \mathrm{N}, 20.03$.

5-(2-Hydroxy-5-(4-Methoxyphenyl)Diazenyl) Phenyl)-2,8-Dithioxo-2, 3, 5, 8, 9, 10-Hexahydropyrido[2,3-D:6,5d']dipyrimidine-4,6-(IH,7H)-Dione (IIIb)

Yield (80\%), greyish white crystals;; m.p. > 300 ${ }^{\circ} \mathrm{C}$; IR $\left(\mathrm{cm}^{-1}\right)$ : $1669(\mathrm{C}=\mathrm{O}), 3257(\mathrm{NH}), 3419(\mathrm{OH}) ;{ }^{1} \mathrm{H}$ NMR $\delta 3.77(\mathrm{~s}$, $\left.3 \mathrm{H}, \mathrm{OCH}_{3}\right), 5.29$ (s, $1 \mathrm{H}$, pyridine), 6.82-6.91 (m, 5H, H-3 $\left., 3 \backslash, 5,2 \mathrm{NH}\right), 7.54-7.57$ (m, 2H, H-6 $\left.4^{`}\right), 7.80$ (d, $J=8.4 \mathrm{~Hz}$, $\left.2 \mathrm{H}, \mathrm{H}-2 \backslash 6^{\prime}\right), 11.58-11.62$ (m, 3H, 3NH), 12.14 (s, 1H, OH); ${ }^{13} \mathrm{C}$ NMR $\delta 29.4,56.5,90.5,113.9,115.8,121.9,123.9$, 125.9, 125.8, 144.7, 145.5, 153.9, 161.8, 164.3, 166.9, 174.5; EIMS (m/z) $507\left(\mathrm{M}^{+}, 24.52 \%\right)$. Elemental analysis of $\mathrm{C}_{22} \mathrm{H}_{17} \mathrm{~N}_{7} \mathrm{O}_{4} \mathrm{~S}_{2}: \mathrm{C}, 52.06 ; \mathrm{H}, 3.38 ; \mathrm{N}, 19.32$. Found: C, 52.00; H, 3.50; N, 19.53 .

5(5-((3-Chloro-4-Fluorophenyl) Diazenyl)-2-Hydroxyphenyl)-2, 8- Dithioxo-2, 3, 5, 8, 9, 10-Hexahydropyrido [2,3-D:6,5d']Dipyrimidine-4,6-(IH,7H)-Dione (IIIc)

Yield (66\%), whitish grey crystals, m.p. $>300^{\circ} \mathrm{C}$; IR $\left(\mathrm{cm}^{-1}\right)$ : $1641(\mathrm{C}=\mathrm{O}), 3040(\mathrm{ArH}), 3150(\mathrm{NH}), 3422(\mathrm{OH}) ;{ }^{1} \mathrm{H}$ NMR $\delta$ $5.31\left(\mathrm{~s}, 1 \mathrm{H}\right.$, pyridine), 6.68-6.89 (m, 4H, H-3 $\left.\left., 5^{\backslash}, 2 \mathrm{NH}\right), 7.11-7.21\left(\mathrm{~m}, 2 \mathrm{H}, \mathrm{H}-4^{\backslash}, 6^{\prime}\right), 7.59(\mathrm{~s}, 1 \mathrm{H}, \mathrm{H}-6)^{\dagger}\right), 7.83(\mathrm{~s}, 1 \mathrm{H}$, H-2 ), 11.49-11.90 (s, 3H, 3NH), 12.01 (s, 1H, OH); ${ }^{13} \mathrm{C}$ NMR $\delta 29.7,91.0,115.8,117.9,121.2,121.2,122.3,123.4$, 
125.4, 126.9, 145.1, 149.3, 153.36, 160.0, 162.8, 168.0, 173.0; EIMS (m/z) $529\left(\mathrm{M}^{+}, 29.39 \%\right), 67$ (100\%). Elemental analysis of $\mathrm{C}_{21} \mathrm{H}_{13} \mathrm{ClFN}_{7} \mathrm{O}_{3} \mathrm{~S}_{2}$ : C, 47.59; H, 2.47; N, 18.50. Found: C, 47.50; H, 2.45; N, 18.54.

5-(5-((3,4-Dimethoxyphenyl-2-Diazenyl)-2-Hydroxyphenyl)-2, 8- Dithioxo-2, 3, 5, 8, 9, I0-Hexahydropyrido[2,3-D:6,5d ']Dipyrimidine-4,6-(IH,7H)-Dione (IIId)

Yield $(80 \%)$, yellow crystals, m.p. $>300{ }^{\circ} \mathrm{C}$; IR $\left(\mathrm{cm}^{-1}\right)$ : $3419(\mathrm{OH}), 3215(\mathrm{NH}), 1667(\mathrm{C}=\mathrm{O}) ;{ }^{1} \mathrm{H}$ NMR $\delta 3.84(\mathrm{~s}, 3 \mathrm{H}$, $\left.\mathrm{OCH}_{3}\right), 3.86\left(\mathrm{~s}, 3 \mathrm{H}, \mathrm{OCH}_{3}\right), 5.29$ (s, $1 \mathrm{H}$, pyridine), 6.82-6.85 (m, 4H, H-3, $\left.5 \backslash 2 \mathrm{NH}\right), 7.11-7.16(\mathrm{~m}, 2 \mathrm{H}, \mathrm{H}-2 \backslash, 6), 7.54-$ 7.57 (m, 2H, H-6' H-4l), 11.92-11.97 (m, 3H, 3NH), 12.03 (s, 1H, OH); ${ }^{13} \mathrm{C}$ NMR $\delta 31.2,55.9,56.2,90.5,111.6,115.6$, 115.8, 115.9, 121.5, 123.9, 125.7, 145.2, 145.7, 146.7, 151.3, 154.0, 162.8, 166.5, 173.7; EIMS (m/z) $537\left(\mathrm{M}^{+}, 32.07 \%\right)$. Elemental analysis of $\mathrm{C}_{23} \mathrm{H}_{19} \mathrm{~N}_{7} \mathrm{O}_{5} \mathrm{~S}_{2}$ : C, 51.39; H, 3.56; N, 18.24. Found: C, 51.55; H, 3.45; N, 18.03 .

5-(5-((3,4-Dichlorophenyl-2-Diazenyl)-2-Hydroxyphenyl)-2, 8- Dithioxo-2, 3, 5, 8, 9, 10-Hexahydropyrido[2,3-D:6,5d'] Dipyrimidine-4,6-(IH,7H)-Dione (IIle)

Whitish yellow crystals (yield 75\%), m.p. > 300 ${ }^{\circ}$; IR $\left(\mathrm{cm}^{-1}\right)$; $3416(\mathrm{OH}), 3180(\mathrm{NH}), 1652(\mathrm{C}=\mathrm{O})$; ${ }^{1} \mathrm{H}$ NMR $\delta 5.31(\mathrm{~s}$, $1 \mathrm{H}$, pyridine $\mathrm{CH}$ ), 6.61-6.67 (m, 3H, H-3`, 2NH), 6.87 (d, $\left.J=8.4 \mathrm{~Hz}, 1 \mathrm{H}, \mathrm{H}-5^{`}\right), 7.65-7.71$ (m, 2H, H-4 , H-6), 7.77 (s, $\left.1 \mathrm{H}, \mathrm{H}-6^{\prime}\right), 7.96$ (s,1H, H-2'), 11.52-11.88 (s, 3H, 3NH), 12.02 (s, 1H, OH); ${ }^{13} \mathrm{C}$ NMR $\delta 29.7,89.0,115.8,121.1,121.8$, 122.4 125.5, 129.3, 135.3, 145.1, 153.3, 154.3, 160.6, 163.1, 173.0; EIMS (m/z) $545\left(\mathrm{M}^{+}, 20.55 \%\right)$. Elemental analysis of $\mathrm{C}_{21} \mathrm{H}_{13} \mathrm{Cl}_{2} \mathrm{~N}_{7} \mathrm{O}_{3} \mathrm{~S}_{2}$ : C, 46.16; H, 2.40; N, 17.94. Found: C, 46.00; H, 2.56; N, 18.23.

Ethyl (E)-4-((3-(4,6-Dioxo-2,8-Dithioxo-I,2,3,4,5,6,7,8,9, I0-Decahydropyrido[2,3-D:6,5-D']Dipyrimidin-5-YI)4-Hydroxyphenyl)Diazenyl)Benzoate (IIIf)

Yield (82\%), yellowish white crystals, m.p. $>300^{\circ} \mathrm{C}$; IR $\left(\mathrm{cm}^{-1}\right)$ : $1686(\mathrm{C}=\mathrm{O}), 3229(\mathrm{NH}), 3451(\mathrm{OH}) ;{ }^{1} \mathrm{H} \mathrm{NMR} \delta, 1.35(\mathrm{t}$, $\left.J=6.8 \mathrm{~Hz}, 3 \mathrm{H}, \mathrm{CH}_{3}\right), 3.36\left(\mathrm{q}, \mathrm{J}=6.8 \mathrm{~Hz}, 2 \mathrm{H}, \mathrm{CH}_{2}\right), 5.31$ (s, $1 \mathrm{H}$, pyridine), 6.63-6.89 (m, 3H, H-3, $\left.2 \mathrm{NH}\right), 7.65-7.68(\mathrm{~m}$, $\left.2 \mathrm{H}, \mathrm{H}-4^{\backslash}, 6^{\prime}\right), 7.88$ (d, $\left.J=8.4 \mathrm{~Hz}, 2 \mathrm{H}, \mathrm{H}-3^{\backslash}, 5^{\backslash}\right), 8.11$ (d, $\left.J=8.4 \mathrm{~Hz}, 2 \mathrm{H}, \mathrm{H}-2^{\backslash}, 6^{\prime}\right), 11.90-11.91(\mathrm{~s}, 3 \mathrm{H}, 3 \mathrm{NH}), 12.06(\mathrm{~s}, 1 \mathrm{H}$, $\mathrm{OH}) ;{ }^{13} \mathrm{C}$ NMR $\delta, 14.6,29.7,61.4,90.7,115.8,121.6,122.6,123.2,125.7,130.8,131.0,145.5,153.3,155.3,160.5$, 163.1, 165.7, 172.9; EIMS (m/z) $549\left(\mathrm{M}^{+}, 18.52 \%\right)$. Elemental analysis of $\mathrm{C}_{24} \mathrm{H}_{19} \mathrm{~N}_{7} \mathrm{O}_{5} \mathrm{~S}_{2}: \mathrm{C}, 52.45 ; \mathrm{H}, 3.48 ; \mathrm{N}, 17.84$. Found: C, 52.55; H, 3.52; N, 18.01 .

(E)-5-(5-((4-Bromophenyl) Diazenyl)-2-Hydroxyphenyl)-2.8-Dithioxo-2, 3, 5,8,9,10-Hexahydropyrido [2,3-D:6,5-D’] Dipyrimidine-4,6(IH,7H)-Dione (IIIg)

Yield (75\%), yellowish white crystals, m.p. $>300^{\circ} \mathrm{C}$; IR $\left(\mathrm{cm}^{-1}\right)$ : $1657(\mathrm{C}=\mathrm{O}), 3185(\mathrm{NH}), 3413(\mathrm{OH}) ;{ }^{1} \mathrm{H}$ NMR $\delta, 5.30(\mathrm{~s}$, $1 \mathrm{H}$, pyridine), 6.63-6.68 (m, 4H, H-3, 4 ', $2 \mathrm{NH}), 7.62-7.65$ (m, 3H, H-6, 3\, 5\), 7.73 (d, 1H, J=8 Hz, H-2 ', H-6), 11.92$12.01(\mathrm{~m}, 3 \mathrm{H}, 3 \mathrm{NH}), 12.06(\mathrm{~s}, 1 \mathrm{H}, \mathrm{OH}) ;{ }^{13} \mathrm{C} \mathrm{NMR} \delta 29.7,78.6,115.7,121.2,123.8,124.4,125.6,126.8,132.8,145.2$, 151.5, 153.3, 159.8, 163.1, 175.0; EIMS (m/z) $556\left(\mathrm{M}^{+}, 15.28 \%\right)$. Elemental analysis of $\mathrm{C}_{21} \mathrm{H}_{14} \mathrm{BrN}_{7} \mathrm{O}_{3} \mathrm{~S}_{2}: \mathrm{C}, 45.53 ; \mathrm{H}$, 2.54; N, 17.62. Found: C, 45.33; H, 2.50; N, 17.60 .

Ethyl (E)-4-((5-(4,6-Dioxo-2,8-Dithioxo-I,2,3,4,5,6,7,8,9, I0-Decahydropyrido[2,3-D:6,5-D']Dipyrimidin-5-YI)2,4-Dimethoxyphenyl)Diazenyl)Benzoate (IIIh)

Yield (70\%), yellowish white crystals, m.p. $>300^{\circ} \mathrm{C}$; IR $\left(\mathrm{cm}^{-1}\right)$ : $1645(\mathrm{C}=\mathrm{O}), 3425(\mathrm{NH}) ;{ }^{1} \mathrm{H}$ NMR $\delta 1.33(\mathrm{t}, J=7.2 \mathrm{~Hz}$, $\left.3 \mathrm{H}, \mathrm{CH}_{3}\right), 3.73\left(\mathrm{~s}, 3 \mathrm{H}, \mathrm{OCH}_{3}\right), 3.74\left(\mathrm{~s}, 3 \mathrm{H}, \mathrm{OCH}_{3}\right), 4.33$ (q, $\left.J=7.2 \mathrm{~Hz}, 2 \mathrm{H}, \mathrm{CH}_{2}\right), 4.75(\mathrm{~s}, 1 \mathrm{H}$, pyridine $\mathrm{CH}), 6.42-6.56$ (m, 3H, H-3', 2NH), 7.53 (s, $\left.1 \mathrm{H}, \mathrm{H}-6^{\prime}\right), 8.12$ (d, $\left.J=8.4 \mathrm{~Hz}, 2 \mathrm{H}, \mathrm{H}-3^{`}, 5^{`}\right), 8.13$ (d, $\left.J=8.4 \mathrm{~Hz}, 2 \mathrm{H}, \mathrm{H}-2^{\backslash}, 6^{\prime}\right), 10.37$ (s, $1 \mathrm{H}$, $\mathrm{NH}), 11.68(\mathrm{~s}, 2 \mathrm{H}, 2 \mathrm{NH}) ;{ }^{13} \mathrm{C}$ NMR $\delta, 14.6,19.0,56.4,56.5,61.3,85.7,101.2,115.6,122.4,125.2,130.6,130.9,153.2$, 156.6, 165.1, 167.3, 168.7, 174.9; EIMS (m/z) $593\left(\mathrm{M}^{+}, 8.69 \%\right)$. Elemental analysis of $\mathrm{C}_{26} \mathrm{H}_{23} \mathrm{~N}_{7} \mathrm{O}_{6} \mathrm{~S}_{2}$ : C, 52.61; H, 3.91; N, 16.52. Found: C, 52.51; H, 4.03; N, 16.43 .

(E)-5-(5-((4-(Benzo[D]thiazol-2-YI)Phenyl)Diazenyl)-2-Hydroxyphenyl)-2,8-Dithioxo-2,3,5,8,9, I0-Hexahydropyrido [2,3-D:6,5-D']Dipyrimidine-4,6(IH,7H)-Dione (Illi)

Yield $(93 \%)$, whitish yellow crystals, m.p. > 300 $\mathrm{C}^{\circ}$ IR $\left(\mathrm{cm}^{-1}\right)$ : 1172(C=S), $1651(\mathrm{C}=\mathrm{O}), 3181(\mathrm{NH}), 3419(\mathrm{OH})$; 
${ }^{1} \mathrm{H}$ NMR, $\delta 5.35$ (s, 1H, pyridine $\left.\mathrm{CH}\right), 6.89-7.48$ (m, 6H, H-3 $\left., 4 \backslash, 3 \backslash 4 \backslash, 2 \mathrm{NH}\right), 7.53-7.77$ (m, 3H, H-6 $\left.3^{\backslash}, 5 \backslash\right), 7.69$ (d, $1 \mathrm{H}$, $\left.J=8 \mathrm{~Hz}, \mathrm{H}-2^{\backslash}, 6^{\dagger}\right), 8.13-8.23\left(\mathrm{~m}, 2 \mathrm{H}, \mathrm{H}-2,6^{\dagger}\right), 11.92-12.01(\mathrm{~m}, 3 \mathrm{H}, 3 \mathrm{NH}), 12.06$ (s, $\left.1 \mathrm{H}, \mathrm{OH}\right) ;{ }^{13} \mathrm{C}$ NMR $\delta 29.7,90.8$, $115.8,121.3,122.8,123.4,123.8,125.8,126.21,127.2,134.3,135.1,145.5,153.3,154.0,154.0,160.1,166.6,166.8$, 173.0; EIMS (m/z) $610\left(\mathrm{M}^{+}, 6.46 \%\right)$. Elemental analysis of $\mathrm{C}_{28} \mathrm{H}_{18} \mathrm{~N}_{8} \mathrm{O}_{3} \mathrm{~S}_{3}: \mathrm{C}, 55.07 ; \mathrm{H}, 2.97 ; \mathrm{N}, 18.35$. Found: C, 55.38; $\mathrm{H}, 3.12 ; \mathrm{N}, 18.74$.

\section{Pharmacological Activity Studies}

All utilized procedures in the pharmacological evaluation were carried out as described earlier. Colorimetric assay of COXs ${ }^{20}$ anti-inflammatory activity (in-vivo), ${ }^{40}$ ulcerogenic liability ${ }^{52}$ were cited in the Supplementary Materials.

\section{Molecular Docking}

The virtual docking study was performed by utilizing the x-ray crystal structure of COX-2 enzyme (pdb code: 1CX2). ${ }^{28}$ Ligand and protein preparation (3D protonation for the amino acid side chain of enzyme, addition of hydrogen atoms, and deletion of all water of crystallization away from the active site) was performed using MOE software (version 2010, Chemical Computing Group Inc., QC, Canada). The pyridopyrimidinones compounds were sketched in their threedimensional (3D) structures by Chemo-Draw, protonated, and subjected to energy minimization. Molecular docking of these compounds has been applied, amino acid interactions were examined, and the hydrogen bond lengths were recorded.

\section{Statistical Analysis}

The significant difference for groups was measured utilizing one-way ANOVA followed by Dunnett's test. Significant differences are at $* \mathrm{P}>0.05,{ }^{*} \mathrm{P}>0.01$ and $* * * \mathrm{P}>0.001$, and GraphPad Prism software (version 5) was used for statistical tests (version 5).

\section{Acknowledgments}

This work was funded by the Deanship of Scientific Research at Jouf University under grant No (DSR-2021-01-0303)".

Also, authors thanks Prof. Hossam M. Hassan, Vice Dean of the Faculty of Pharmacy, Nahda University Beni-Suef Egypt. For supporting this work.

\section{Disclosure}

The authors report no conflicts of interest in this work.

\section{References}

1. Medzhitov R. Origin and physiological roles of inflammation. Nature. 2008;454(7203):428. doi:10.1038/nature07201

2. Nathan C. Points of control in inflammation. Nature. 2002;420(6917):846. doi:10.1038/nature01320

3. Kolls JK, Lindén A. Interleukin-17 family members and inflammation. Immunity. 2004;21(4):467-476. doi:10.1016/j.immuni.2004.08.018

4. Nathan C, Ding A. Nonresolving inflammation. Cell. 2010;140(6):871-882. doi:10.1016/j.cell.2010.02.029

5. Levine B, Mizushima N, Virgin HW. Autophagy in immunity and inflammation. Nature. 2011;469(7330):323. doi:10.1038/nature09782

6. Olefsky JM, Glass CK. Macrophages, inflammation, and insulin resistance. Annu Rev Physiol. 2010;72(1):219-246. doi:10.1146/annurev-physiol $-021909-135846$

7. Abdellatif KR, Abdelgawad MA, Labib MB, Zidan TH. Synthesis and biological evaluation of new diarylpyrazole and triarylimidazoline derivatives as selective cox-2 inhibitors. Arch Pharm. 2017;350(8):1600386. doi:10.1002/ardp.201600386

8. Vane JR, Botting RM. Mechanism of action of nonsteroidal anti-inflammatory drugs. Am J Med. 1998;104(3):2S-8S. doi:10.1016/S0002-9343(97) 00203-9

9. Brune K, Patrignani P. New insights into the use of currently available non-steroidal anti-inflammatory drugs. J Pain Res. 2015;8:105. doi:10.2147/ JPR.S75160

10. Hla T, Neilson K. Human cyclooxygenase-2 cDNA. Proc Nat Acad Sci. 1992;89(16):7384-7388. doi:10.1073/pnas.89.16.7384

11. Abdellatif K, Abdelall E, Bakr R. Nitric oxide-NSAIDs donor prodrugs as hybrid safe anti-inflammatory agents. Curr Top Med Chem. 2017;17 (8):941-955. doi:10.2174/1568026616666160927153435

12. Abdelgawad MA, Bakr RB, Omar HA. Design, synthesis and biological evaluation of some novel benzothiazole/benzoxazole and/or benzimidazole derivatives incorporating a pyrazole scaffold as antiproliferative agents. Bioorg Chem. 2017;74:82-90. doi:10.1016/j.bioorg.2017.07.007

13. Bakr RB, Azouz AA, Abdellatif KR. Synthesis, cyclooxygenase inhibition, anti-inflammatory evaluation and ulcerogenic liability of new 1-phenylpyrazolo [3, 4-d] pyrimidine derivatives. J Enzyme Inhib Med Chem. 2016;31:6-12. doi:10.1080/14756366.2016.1186018 
14. Abdellatif KR, Abdelgawad MA, Elshemy HA, Alsayed SS, Kamel G. Synthesis and anti-inflammatory evaluation of new 1, 3, 5-triaryl-4, 5-dihydro-1h-pyrazole derivatives possessing an aminosulphonyl pharmacophore. Arch Pharm Res. 2015;38(11):1932-1942. doi:10.1007/s12272015-0606-7

15. Wang D, DuBois RN. The role of cox-2 in intestinal inflammation and colorectal cancer. Oncogene. 2010;29(6):781. doi:10.1038/onc.2009.421

16. Griswold DE, Adams JL. Constitutive cyclooxygenase (cox-1) and inducible cyclooxygenase (cox-2): rationale for selective inhibition and progress to date. Med Res Rev. 1996;16(2):181-206. doi:10.1002/(SICI)1098-1128(199603)16:2<181::AID-MED3>3.0.CO;2-X

17. Lazzaroni M, Bianchi Porro G. Gastrointestinal side-effects of traditional non-steroidal anti-inflammatory drugs and new formulations. Aliment Pharmacol Ther. 2004;20:48-58. doi:10.1111/j.1365-2036.2004.02037.x

18. Vane J, Bakhle Y, Botting R. Cyclooxygenases 1 and 2. Annu Rev Pharmacol Toxicol. 1998;38(1):97-120. doi:10.1146/annurev.pharmtox.38.1.97

19. Abdelrahman MH, Youssif BG, Abdelazeem AH, et al. Synthesis, biological evaluation, docking study and ulcerogenicity profiling of some novel quinoline-2-carboxamides as dual coxs/lox inhibitors endowed with anti-inflammatory activity. Eur J Med Chem. 2017;127:972-985. doi:10.1016/j. ejmech.2016.11.006

20. Abdelgawad MA, Bakr RB, El-Gendy AO, Kamel GM, Azouz AA, Bukhari SNA. Discovery of a cox-2 selective inhibitor hit with anti-inflammatory activity and gastric ulcer protective effect. Future Med Chem. 2017;9(16):1899-1912. doi:10.4155/fmc-2017-0115

21. Lacerda RB, de Lima CK, da Silva LL, et al. Discovery of novel analgesic and anti-inflammatory 3-arylamine-imidazo [1, 2-a] pyridine symbiotic prototypes. Bioorg Med Chem. 2009;17(1):74-84. doi:10.1016/j.bmc.2008.11.018

22. Abdelgawad MA, Bakr RB, Azouz AA. Novel pyrimidine-pyridine hybrids: synthesis, cyclooxygenase inhibition, anti-inflammatory activity and ulcerogenic liability. Bioorg Chem. 2018;77:339-348. doi:10.1016/j.bioorg.2018.01.028

23. Girgis AS, Mishriky N, Ellithey M, Hosni HM, Farag H. Novel synthesis of [1]-benzothiepino [5, 4-b] pyridine-3-carbonitriles and their anti-inflammatory properties. Bioorg Med Chem. 2007;15(6):2403-2413. doi:10.1016/j.bmc.2007.01.015

24. Renard J-F, Lecomte F, Hubert P, de Leval X, Pirotte B. N-(3-arylaminopyridin-4-yl) alkanesulfonamides as pyridine analogs of nimesulide: cyclooxygenases inhibition, anti-inflammatory studies and insight on metabolism. Eur J Med Chem. 2014;74:12-22. doi:10.1016/j. ejmech.2013.12.033

25. Chung S-T, Huang W-H, Huang C-K, et al. Synthesis and anti-inflammatory activities of 4h-chromene and chromeno [2, 3-b] pyridine derivatives. Res Chem Intermed. 2016;42(2):1195-1215. doi:10.1007/s11164-015-2081-7

26. Lu X, Zhang H, Li X, et al. Design, synthesis and biological evaluation of pyridine acyl sulfonamide derivatives as novel cox-2 inhibitors. Bioorg Med Chem. 2011;19(22):6827-6832. doi:10.1016/j.bmc.2011.09.034

27. Bekhit AA, Fahmy HT, Rostom SA, Baraka AM. Design and synthesis of some substituted 1h-pyrazolyl-thiazolo [4, 5-d] pyrimidines as antiinflammatory-antimicrobial agents. Eur J Med Chem. 2003;38(1):27-36. doi:10.1016/S0223-5234(02)00009-0

28. Sondhi SM, Singh N, Johar M, Kumar A. Synthesis, anti-inflammatory and analgesic activities evaluation of some mono, bi and tricyclic pyrimidine derivatives. Bioorg Med Chem. 2005;13(22):6158-6166. doi:10.1016/j.bmc.2005.06.063

29. Keche AP, Hatnapure GD, Tale RH, Rodge AH, Birajdar SS, Kamble VM. A novel pyrimidine derivatives with aryl urea, thiourea and sulfonamide moieties: synthesis, anti-inflammatory and antimicrobial evaluation. Bioorg Med Chem Lett. 2012;22(10):3445-3448. doi:10.1016/j. bmcl.2012.03.092

30. Garjani A, Davaran S, Rashidi M, Malek N. Protective effects of some azo derivatives of 5-aminosalicylic acid and their pegylated prodrugs on acetic acid-induced rat colitis. DARU J Pharmaceut Sci. 2004;12:24-30.

31. Abdu-Allah HH, El-Shorbagi A-NA, Abdel-Moty SG, El-Awady R, Abdel-Alim A. 5-aminosalyclic acid (5-asa): a unique anti-inflammatory salicylate. Med Chem. 2016;6(05):306-315. doi:10.4172/2161-0444.1000361

32. Sheng SF, Zheng HX, Liu J, Zhao ZB. Synthesis of phenol-class azo derivatives of 4-aminosalicylic acid. Chin Chem Lett. $2008 ; 19(4): 419-422$. doi:10.1016/j.cclet.2008.01.042

33. Hassan GS, Soliman GA. Design, synthesis and anti-ulcerogenic effect of some of furo-salicylic acid derivatives on acetic acid-induced ulcerative colitis. Eur J Med Chem. 2010;45(9):4104-4112. doi:10.1016/j.ejmech.2010.05.071

34. Mohamed MS, Awad SM, Sayed AI. Synthesis of certain pyrimidine derivatives as antimicrobial agents and anti-inflammatory agents. Molecules. 2010;15(3):1882-1890. doi:10.3390/molecules15031882

35. Abdelgawad MA, Labib MB, Ali WA, Kamel G, Azouz AA, EL-Shaymaa E-N. Design, synthesis, analgesic, anti-inflammatory activity of novel pyrazolones possessing aminosulfonyl pharmacophore as inhibitors of cox-2/5-lox enzymes: histopathological and docking studies. Bioorg Chem. 2018;78:103-114. doi:10.1016/j.bioorg.2018.03.011

36. Abdelgawad MA, Labib MB, Abdel-Latif M. Pyrazole-hydrazone derivatives as anti-inflammatory agents: design, synthesis, biological evaluation, cox-1, 2/5-lox inhibition and docking study. Bioorg Chem. 2017;74:212-220. doi:10.1016/j.bioorg.2017.08.014

37. Abdelgawad MA, Mohamed AM, Musa A, Mostafa EM, Awad HM. Synthesis, chromatographic separation and antimicrobial evolution of new azoquinoline-8-ol. J Pharmaceut Sci Res. 2018;10:1314-1318.

38. Bakr RB, Elkanzi NA, Ghoneim AA, Moustafa S. Synthesis, molecular docking studies and in vitro antimicrobial evaluation of novel pyrimido [1, 2-a] quinoxaline and triazino [4, 3-a]-quinoxaline derivatives. Heterocycles. 2018;96(11):1941-1957. doi:10.3987/COM-18-13955

39. Elkanzi NA, Bakr RB, Ghoneim AA. Design, synthesis, molecular modeling study, and antimicrobial activity of some novel pyrano [2, 3-b] pyridine and pyrrolo [2, 3-b] pyrano [2.3-d] pyridine derivatives. J Heterocycl Chem. 2019;56:406-416.

40. Bakr RB, Ghoneim AA, Azouz AA. Selective cyclooxygenase inhibition and ulcerogenic liability of some newly prepared anti-inflammatory agents having thiazolo [4, 5-d] pyrimidine scaffold. Bioorg Chem. 2019;88:102964. doi:10.1016/j.bioorg.2019.102964

41. Belal A, Abdelgawad MA. New benzothiazole/benzoxazole-pyrazole hybrids with potential as cox inhibitors: design, synthesis and anticancer activity evaluation. Res Chem Intermed. 2017;43(7):3859-3872. doi:10.1007/s11164-016-2851-x

42. Oraby AK, Abdellatif KR, Abdelgawad MA, Attia KM, Dawe LN, Georghiou PE. 2, 4-disubstituted phenylhydrazonopyrazolone and isoxazolone derivatives as antibacterial agents: synthesis, preliminary biological evaluation and docking studies. ChemistrySelect. 2018;3(11):3295-3301. doi:10.1002/slct.201800174

43. Abdellatif RA, Abdelgawad M, Elshemy. AH, Kahk M, El Amir M. Design, synthesis, antioxidant and anticancer activity of new coumarin derivatives linked with thiazole, isoxazole or pyrazole moiety. Lett Drug Des Discov. 2017;14(7):773-781. doi:10.2174/ 1570180813666161026153743 
44. Bakr B, Mehany. BM, Abdellatif RA. Synthesis, egfr inhibition and anti-cancer activity of new 3, 6-dimethyl-1-phenyl-4-(substituted-methoxy) pyrazolo [3, 4-d] pyrimidine derivatives. Curr Med Chem Anticancer Agents. 2017;17:1389-1400.

45. Taddei D, Slawin AM, Woollins JD. 2-(benzylsulfanyl)-6-chloro-9-isopropylpurine, a valuable intermediate in the synthesis of diaminopurine cyclin dependent kinase inhibitors. European J Org Chem. 2005;2005(5):939-947. doi:10.1002/ejoc.200400748

46. Bhuvaneswari K, Nagasundaram N, Lalitha A. Synthesis, anti-inflammatory activity, and molecular docking study of novel azo bis antipyrine derivatives against cyclooxygenase-2 enzyme. J Chin Chem Soc. 2021;68:27-33.

47. Korade SN, Patil JD, Gaikwad DS, et al. Synthesis and biological activities of novel aryldiazo substituted heterocycles. Org Prep Proced Int. 2020;52(2):147-165. doi:10.1080/00304948.2020.1716625

48. Korade SN, Pore DM. Basic ionic liquid [DPPA] cl- catalyzed synthesis of fluorescent 3-acetoacetyl- 6-aryldiazenyl-coumarins. ChemistrySelect. 2019;4:4804-4808. doi:10.1002/slct.201900332

49. Kurumbail RG, Stevens AM, Gierse JK, et al. Structural basis for selective inhibition of cyclooxygenase-2 by anti-inflammatory agents. Nature. 1996;384(6610):644-648. doi:10.1038/384644a0

50. Khanmohammadi H, Erfantalab M, Bayat A, Babaei A, Sohrabi M. New 1, 2, 4-triazole-based azo-azomethine dyes. Part ii: synthesis, characterization, electrochemical properties and computational studies. Spectrochim Acta a Mol Biomol Spectrosc. 2012;97:876-884. doi:10.1016/j.saa.2012.07.041

51. Arbabi HA, Soltani SS, Salehi H, Rezazadeh S, Zonouzi A, Toosibashi M. Convenient synthesis of heterocyclic azo dyes in the class of pyranopyrazoles and chromenes. J Chem Res. 2018;42(2):68-72. doi:10.3184/174751918X15177611816526

52. Cho $\mathrm{CH}$, Ogle CW. Cholinergic-mediated gastric mast cell degranulation with subsequent histamine h1-and h2-receptor activation in stress ulceration in rats. Eur J Pharmacol. 1979;55(1):23-33. doi:10.1016/0014-2999(79)90144-4

Journal of Inflammation Research

\section{Publish your work in this journal}

The Journal of Inflammation Research is an international, peer-reviewed open-access journal that welcomes laboratory and clinical findings on the molecular basis, cell biology and pharmacology of inflammation including original research, reviews, symposium reports, hypothesis formation and commentaries on: acute/chronic inflammation; mediators of inflammation; cellular processes; molecular mechanisms; pharmacology and novel anti-inflammatory drugs; clinical conditions involving inflammation. The manuscript management system is completely online and includes a very quick and fair peer-review system. Visit http://www.dovepress.com/testimonials.php to read real quotes from published authors.

Submit your manuscript here: https://www.dovepress.com/journal-of-inflammation-research-journal 